\title{
Competency of Digital Technology: The Maturity Levels of Teachers and Students in Vocational Education in Indonesia
}

\author{
Melinda Astuti ${ }^{*}$, Putu Sudira ${ }^{2}$, Farid Mutohhari ${ }^{3}$, Muhammad Nurtanto $^{4}$ iD \\ ${ }^{1,2,3}$ Postgraduate Program, Technology and Vocational Education, Yogyakarta State University, Indonesia \\ ${ }^{4}$ Department of Mechanical Engineering Education, Universitas Sultan Ageng Tirtayasa, Indonesia
}

\section{A R T I C L E I N F O}

Article history:

Received April 09, 2021

Revised April 10, 2021

Accepted May 04, 2021

Available online May 25, 2021

\section{Kata Kunci:}

Tingkat Kematangan

Teknologi Digital

Pendidikan Kejuruan

Keywords:

Maturity Levels

Digital Technology

Vocational Education

\begin{abstract}
A B S T R A K
Salah satu kebutuhan kompetensi dunia kerja dalam abad 21 dan era revolusi industri 4.0 adalah kompetensi dalam menggunakan teknologi digital. Kematangan teknologi digital dalam mendukung pencapaian kompetensi industri 4.0 kurang mendapat perhatian serius dari pendidikan vokasi. Guru masih memiliki tingkat kematangan yang rendah dalam menguasai teknologi digital. Penelitian ini bertujuan untuk menganalisis tingkat kematangan guru dan siswa di pendidikan vokasional dalam menguasai pembelajaran menggunakan teknologi digital. Penelitian survey menggunakan design yang dikembangkan oleh Rea \& Parker. Sejumlah 233 siswa sekolah menengah kejuruan dilibatkan sebagai sampel penelitian. Data dikumpulkan menggunakan teknik kuesioner dengan instrument angket berskala empat likert. Data yang terkumpul dianalisis menggunakan statistik deskriptif dan statistik inferensial uji t. Hasil penelitian menunjukkan bahwa tingkat kematangan teknologi digital pada guru dan siswa berurutan mulai dari peduli, literasi, kapabilitas, kreativitas, dan kritis menggunakan teknologi digital. Semua tingkat kematangan tersebut masuk dalam kategori yang rendah. Berbagai pelatihan dan innovasi pembelajaran yang relevan dengan keterkaitan kompetensi penguasaan teknologi digital sangat penting untuk ditingkatkan.
\end{abstract}

\section{A B S T R A C T}

One of the needs for competence in the world of work in the 21st century and the era of the industrial revolution 4.0 is competence in using digital technology. The maturity of digital technology in supporting industrial 4.0 competencies has received less serious attention from vocational education. Teachers still have a low level of maturity in mastering digital technology. This study aims to analyze the maturity level of teachers and students in vocational education in mastering learning using digital technology. The survey research uses a design developed by Rea \& Parker. A total of 233 vocational high school students were included as the research sample. Data were collected using a questionnaire technique with a four Likert scale questionnaire instrument. The collected data were analyzed using descriptive statistics and inferential statistics ttest. The results show that the maturity level of digital technology for teachers and students is sequential, starting from caring, literacy, capability, creativity, and being critical of using digital technology. All levels of maturity are included in the low category. Various training and learning innovations relevant to digital technology mastery competencies are significant to be improved.

This is an open access article under the CC BY-SA license.

Copyright (C) 2021 by Author. Published by Universitas Pendidikan Ganesha.

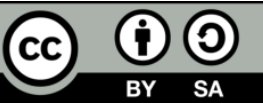

\section{INTRODUCTION}

One of the phenomenal developments in science and technology in the 21 st century is the 4.0 industrial revolution (Hussin, 2018; Miranda et al., 2021; Willya et al., 2019). Digitalization in all fields of activity and work is the main characteristic of this era (Jones, Hutcheson, \& Camba, 2021; Lange, Pohl, \& Santarius, 2020; Pershina, Soppe, \& Thune, 2019). These characteristics have disrupted conventional technology in work and replaced it with new digital technology (Ivanov, Dolgui, \& Sokolov, 2019). The presence of new technology, of course, requires new competencies as well (Llopis-Albert, Rubio, \& Valero, 2021; Xu, David, \& Kim, 2018). Competence in using digital technology is an important key to face the world of work in the revolutionary era 4.0. The workforce must master the technology thoroughly to compete and meet the needs of today's new competencies (Kergroach, 2017; Rotatori, Lee, \& Sleeva, 2021). Thus, it is essential to develop competencybased human resources in the 4.0 industrial revolution era. As one of the sustainable development institutions, vocational education has a role in responding to the need for new competencies in the industrial world (Akhter, Malik, \& Plummer, 2021; Ollikainen \& Karhunen, 2021). The role of vocational education in developing human resource competencies according to current job needs is essential (Miller, 2020; Sudana, Apriyani, \& Nurmasitah, 2019). Through learning, vocational education must teach new competencies, namely competence 
in using digital technology (Devi, Annamalai, \& Veeramuthu, 2020). These competencies must be taught intensively so that the ability to master digital technology possessed by graduates is high and meets the current world of work (Sprenger \& Schwaninger, 2021).

However, the maturity of digital technology in supporting the achievement of industry 4.0 competencies has received less serious attention from vocational education (Ronzhina, Kondyurina, Voronina, Igishev, \& Loginova, 2021; Zhao, Llorente, \& Gómez, 2021). Facts in previous research reveal that teachers still have a low level of maturity in mastering digital technology (Mutohhari, Sofyan, \& Nurtanto, 2021; Zimmer, McTigue, \& Matsuda, 2021). Moreover, currently, teachers are required to use technology in the era of online learning (Amiti, 2020; Cloonan et al., 2020; Garad, Al-Ansi, \& Qamari, 2021; Silalahi, 2020). Online learning has become an obligation during the COVID-19 pandemic (Ariebowo, 2021; Jogezai et al., 2021; Yustina, Syafii, \& Vebrianto, 2020). Teachers must be able to design good online learning. In addition, teachers are required to facilitate students in online learning so that students do not experience difficulties in (Atmojo \& Nugroho, 2020; Nugroho, Ilmiani, \& Rekha, 2021; Sari, Sinaga, Hernani, \& Solfarina, 2020). Teachers must create a fun learning process so that learning objectives can be achieved optimally (Abidah et al., 2020; Dong, Cao, \& Li, 2020; Hanik, 2020). This online learning must also be applied to vocational education.

Several important factors influence the success of vocational education in developing industry 4.0-based competencies. Cyber-based digital technology facilities and infrastructure are essential to educational institutions (Apriansyah, Fransinatra, \& Ririen, 2020; Kim et al., 2020). In addition, the application of learning models and methods must be appropriate to carry out learning that can be oriented to the achievement of industry 4.0-based competencies (Partovi \& Razavi, 2019; Sadeghi \& Sadeghi, 2012; Shahroom \& Hussin, 2018). However, apart from that, the maturity of competence in using digital technology to learn integrated with digital technology is also essential for teachers and students to have (Adnan et al., 2020; Bayles et al., 2021; Sert \& Boynueğri, 2017). The level of maturity in mastering digital technology is one aspect that plays a role in supporting the transformation of industry-based learning 4.0 (Bergdahl, Nouri, \& Fors, 2020; Rizaldi, Nurhayati, \& Fatimah, 2020). Teachers as learning facilitators must have mature mastery of digital technology (Aina \& Tuti, 2020; Bui \& Do Van Dung, 2019). However, students must also have a strong base of mastery as a foundation in forming a high level of maturity in mastering digital technology (Hussin, 2018).

Maturity in using digital technology has a maturity level called the technological competence taxonomy. There are five levels in the taxonomy of technological competence, namely: (1) Awareness for technology that is at the first level or at the lowest level with the condition that it is only limited to knowing and caring about technology; (2) Technological literacy is at the second level whose conditions have been able to understand in depth the uses and benefits of technology; (3) Technology capability is at the third level which is the main competency in operating technology properly; (4) Technological creativity at the fourth level is the ability to find new technologies to solve problems, and; (5) Technological criticism at the highest level, which is the ability to assess and make appropriate and critical decisions regarding a choice of technological findings to be used (Lindvig \& Mathiasen, 2020; Neupokoeva, et al., 2021). The use of technology is currently needed in the world of education (Atmojo \& Nugroho, 2020; Chang et al., 2021; Chang et al., 2020). Teachers and students must master the technology so that the learning process will run smoothly.

Based on the description above, this research will focus on the maturity level of teachers and students in using digital technology to support the achievement of industry 4.0-based learning. Exploration of the maturity level of mastery of digital technology owned by teachers and students needs to be carried out to determine the focus of improvement and retraining to mature the competence of teachers and students in using digital technology (Barragán-Sánchez et al., 2020). This study aims to analyze the maturity level of teachers and students in vocational education in Indonesia.

\section{METHOD}

This research is a survey research using a design developed by Rea \& Parker (Rea \& Parker, 2014). This study aims to explore the level of maturity possessed by teachers and students in using digital technology. The study was conducted in 4 vocational high schools in the Sleman district, divided into public schools and private schools. Some 326 people consisted of teachers and student population in this study. Sampling uses a simple probabilistic random sampling technique, which means all have the same opportunity to be the sample (Sugiyono, 2017). The sample in this study was obtained some 233 people who will be a responder. Here is a sample distribution in this study is shown in Table 1.

Table 1. Distribution of Respondent Data

\begin{tabular}{cccc}
\hline Name of Vocational Education & Status & Students (\%) & Teachers (\%) \\
\hline SMK Negeri 1 Cangkringan & Public School & $45(24.86)$ & $14(26.92)$ \\
\hline
\end{tabular}




\begin{tabular}{lccc}
\hline SMK Negeri 1 Seyegan & Public School & $58(32.04)$ & $18(34.62)$ \\
SMK Muhammadiyah Prambanan & Private School & $42(23.20$ & $12(23.08)$ \\
SMK Muhammadiyah Pakem & Private School & $36(19.89)$ & $8(15.38)$ \\
\hline Total & & $\mathbf{1 8 1}(\mathbf{1 0 0 . 0 0 )}$ & $\mathbf{5 2}(\mathbf{1 0 0 . 0 0 )}$ \\
\hline
\end{tabular}

The data collection technique was carried out using a questionnaire method containing statements related to the maturity of teachers or students in using digital technology. The research instrument uses a questionnaire with a Likert scale design using 4 answer scales, namely Strongly Agree (SA), Agree (A), Disagree (D), Strongly Disagree (SD). Statements in the instrument are prepared based on variables and indicators of maturity level in using technology adopted from opinions Pavlova (Pavlova, 2009). The following is a grid of maturity level questionnaires in using digital technology shown in Table 2.

Table 2. Grid of Research Instrument

\begin{tabular}{lll}
\hline Maturity Levels & Indicators & Item (Distribution) \\
\hline Technological awareness & Following the development & $4(1-4)$ \\
& Care for existence & $3(5-7)$ \\
& Willingness to observe the characteristics & $3(8-10)$ \\
Technological literacy & Comprehensive understanding & $4(11-14)$ \\
& Depth in learning & $2(15-16)$ \\
& Knowledge of the functions and benefits & $4(17-20)$ \\
Technological capability & Technical ability & $4(21-24)$ \\
& Accessibility capabilities & $4(25-28)$ \\
Technological creativity & Discovery ability & $4(29-32)$ \\
& Usefulness of discovery & $4(33-36)$ \\
Technological criticism & Critical in operation & $4(37-40)$ \\
& Critical in choosing technology & $4(41-44)$ \\
\hline
\end{tabular}

Source: (Pavlova, 2009; Sudira, 2020)

The collected data were then analyzed using descriptive and inferential statistics using a quantitative approach. Descriptive analysis is used to describe the average and the percentage of each level of maturity in teachers and students. While the inferential analysis was carried out using an independent sample t test to determine the difference in the average maturity level between teachers and students in using digital technology. The maturity level of each level will be determined based on the criteria in the specified category by adopting the opinion of (Mardapi, 2012). The following are the criteria for determining the maturity level category which is shown in Tables 3 and 4.

Table 3. Maturity Levels Category

\begin{tabular}{cc}
\hline Interval Score & Category \\
\hline$M i+1,5 S D i \leq M \leq M i+3,0 S D i$ & Very High \\
$M i+0 S D i \leq M \leq M i+1,5 S D i$ & High \\
$M i-1,5 S D i \leq M \leq M i+0 S D i$ & Low \\
$M i-3,0 S D i \leq M \leq M i-1,5 S D i$ & Very Low \\
\hline
\end{tabular}

Source: (Mardapi, 2012)

\section{RESULT AND DISCUSSION}

Data on the level of the maturity level of caring for digital technology of teachers and students were obtained from a questionnaire instrument with 10 . The maturity level of caring for digital technology owned by teachers and students was still low. The results showed that the average maturity of teachers was still in the low category. The percentage value of the maturity level of the teacher's technology care is $59.20 \%$, with an average maturity value of 23.68 . In contrast, the percentage of maturity owned by students is $55.30 \%$, with an average difficulty value of 22.12. These results mean that the level of maturity in caring for technology owned by teachers and students is in the lowest category. After knowing the magnitude of the maturity level, an independent sample t-test was carried out to determine the difference in the level of maturity in caring for technology owned by teachers and students. Based on the results of the independent sample t-test above, it is known that the $t$-count value is 1.456 with a significance value of 0.092 . The $t$-count value is $1.756<1.9631$, and the sig value is $0.092>0.050$. Thus, it can be concluded that there is no significant difference between the 
maturity of teachers and students at the level of technology care. Teachers and students have a level of maturity that can be said to be the same and not significantly different.

Data on the maturity level of digital technology literacy of teachers and students were obtained from a questionnaire instrument with 10 . The maturity level of digital technology literacy owned by teachers and students was still low. The results showed that the average maturity of teachers was still in the low category. The teacher's percentage value of the maturity level of digital technology literacy is $56.85 \%$, with an average maturity value of 22.74. Meanwhile, the percentage of maturity possessed by students is $55.20 \%$, with an average difficulty value of 22.08. These results mean that teachers' and students' maturity levels of digital technology literacy are in the lowest category. After knowing the magnitude of the maturity level, then an independent sample t-test was carried out to determine the difference in the maturity level of digital technology literacy owned by teachers and students. Based on the results of the independent sample t-test above, it is known that the $\mathrm{t}$-count value is 1.056 with a significance value of 0.368 . The $\mathrm{t}$-count value is $1.056<1.9631$, and the sig value is $0.368>0.050$. Thus, it can be concluded that there is no significant difference between the maturity of teachers and students at the level of digital technology literacy. Teachers and students have a level of maturity that can be said to be the same and not significantly different.

Maturity level data on the digital technology capabilities of teachers and students were obtained from a questionnaire instrument with a total of 8 statements. The maturity level of digital technology capabilities possessed by teachers and students is still low. The results showed that the average maturity of teachers was still in the low category. The percentage value of the maturity level of the digital technology capabilities of the teacher is $49.94 \%$ with an average maturity value of 15.98 . Meanwhile, the percentage of maturity possessed by students is $49.25 \%$ with an average difficulty score of 15.76 . These results mean that the maturity level of digital technology capabilities of teachers and students is in the lowest category. After knowing the magnitude of the maturity level, then an independent sample t test is carried out to determine the difference in the maturity level of the digital technology capabilities of teachers and students. Based on the results of the independent sample t test above, it is known that the $t$ value is 0.787 with a significance value of 0.511 . The $t$-count value is $0.787<1.9631$ and the sig value is $0.511>0.050$. Thus, it can be concluded that there is no significant difference between the maturity of teachers and students at the level of digital technology capability. Teachers and students have a level of maturity that can be said to be the same and not significantly different.

Maturity level data on the creativity of digital technology teachers and students were obtained from a questionnaire instrument with a total of 8 statements. The maturity level of digital technology creativity possessed by teachers and students is very low. The results showed that the average maturity of teachers was still in a very low category. The percentage value of the maturity level of digital technology creativity owned by the teacher is $42.72 \%$ with an average maturity value of 13.67 . Meanwhile, the percentage of maturity possessed by students is $40.69 \%$ with an average difficulty value of 13.02 . These results mean that the maturity level of digital technology creativity owned by teachers and students is in the very low category. After knowing the magnitude of the maturity level, then an independent sample t test is carried out to determine the difference in the maturity level of the digital technology capabilities of teachers and students. Based on the results of the independent sample t-test above, it is known that the t-count value is 0.899 with a significance value of 0.426 . The $t$-count value is $0.899<1.9631$ and the sig value is $0.426>0.050$. Thus, it can be concluded that there is no significant difference between the maturity of teachers and students on the level of creativity in digital technology. Teachers and students have a level of maturity that can be said to be the same and not significantly different.

Maturity analysis data at a critical level using digital technology for teachers and students were obtained from a questionnaire instrument with a total of 8 statements. The maturity of the critical level of digital technology owned by teachers and students is very low. The results showed that the average maturity of teachers was still in a very low category. The percentage value of the maturity level of critical digital technology owned by the teacher is $41.22 \%$ with an average maturity value of 13.19 . Meanwhile, the percentage of maturity possessed by students is $40.56 \%$ with an average difficulty value of 12.98 . These results mean that the maturity level of critical digital technology owned by teachers and students is in the very low category. After knowing the magnitude of the maturity level, then an independent sample $t$ test is carried out to determine the difference in the maturity level of the digital technology capabilities of teachers and students. Based on the results of the independent sample $t$ test above, it is known that the $t$ count value is 0.810 with a significance value of 0.485 . The t-count value is $0.810<1.9631$ and the sig value is $0.485>0.050$. Thus, it can be concluded that there is no significant difference between the maturity of teachers and students at the critical level of digital technology. Teachers and students have a level of maturity that can be said to be the same and not significantly different.

After knowing each level of maturity possessed by teachers and students, the division of each level is carried out in one path. The aim is to clarify the flow of maturity levels of concern for digital technology to being critical of digital technology. The distribution of the maturity level of digital technology owned by teachers and students is depicted through a line graph. The following distribution of maturity levels is shown in Figure 1. 


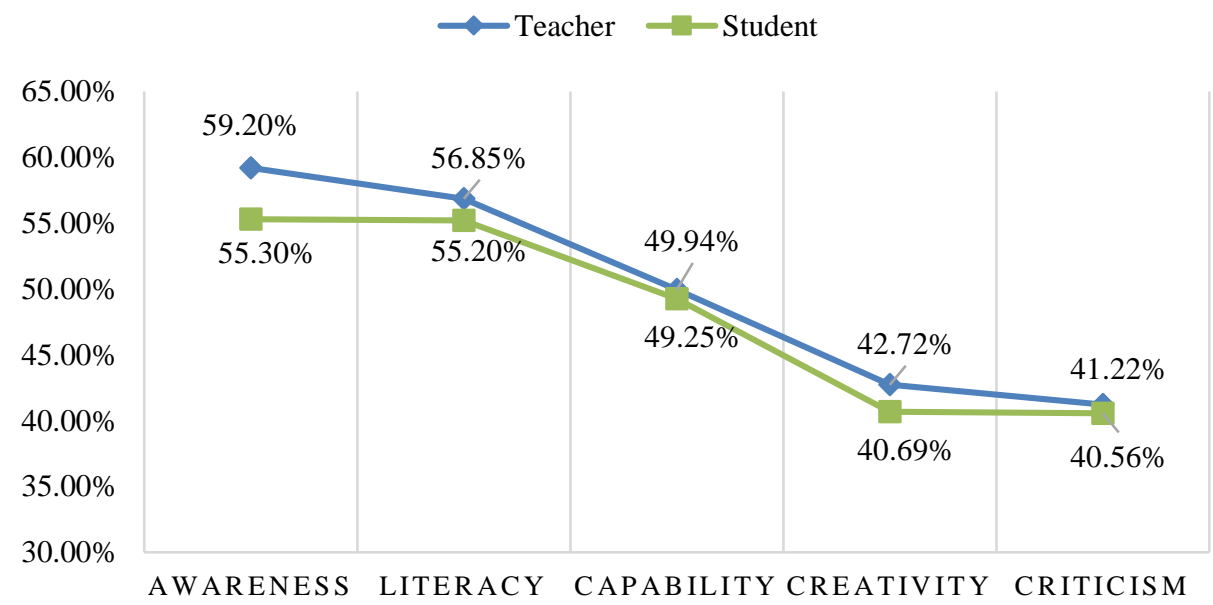

Figure 1. Distribution of Digital Technology Maturity Level

Based on Figure 1, the flow of digital technology maturity levels that are owned by teachers and students is described from the level of digital technology care to digital technology critical. The flow explains that the higher the level of mastery of digital technology, the lower the level of maturity possessed by teachers and students. Thus, the maturity of teachers and students in mastering digital technology is sequential from the first level to the last level. Awareness of digital technology to meet the competency needs of the 21 st century and industry 4.0 is the lowest level. Caring about technology is the basis for shaping digital literacy (Beck et al., 2021; Purnama et al., 2021). Without awareness for digital technology, digital literacy will not be formed (Deja, Rak, \& Bell, 2021; Jang et al., 2021). Meanwhile, digital literacy, which is a comprehensive understanding of digital technology, acts as a foundation in building one's digital technology capabilities (Bergdahl et al., 2020; Liang, Torre, \& Law, 2021; Tham, Burnham, Hocutt, \& Ranade, 2021). Furthermore, without sufficient capability in mastering digital technology, one's creativity in using the technology will be lacking (Sprenger \& Schwaninger, 2021). Likewise, the latter emphasizes that to achieve a critical level in using technology, creativity is needed in using digital technology (Mulyanto et al., 2020; Mutohhari et al., 2021; Yazar Soyadi, 2015).

Maturity in various levels of mastery of digital technology is very important for someone to have today. In the 21 st century and the era of the industrial revolution 4.0 , it is very important for vocational education to properly equip students' digital technology competencies (Malik, 2018; Trilling \& Fadel, 2009). Learners need mature digital competencies to be able to carry out work and problem solving in that era (Nurtanto, Sofyan, Fawaid, \& Rabiman, 2019). The maturity of students' digital technology competencies is influenced by various interrelated factors. Concern for the existence and development of digital technology is a basic factor that students must have (Hendawi \& Nosair, 2020). In addition, students' understanding of digital technology that can support the achievement of 21 st century learning and industry 4.0 is an important factor as the basic foundation of digital technology competence (Falloon, 2020; Lase, 2019). A comprehensive understanding of digital technology is also useful in supporting problem solving in learning (Sadaf \& Johnson, 2017).

The maturity level of digital technology competence in students is also influenced by the maturity of digital technology competence in teachers (Artacho et al., 2020). The teacher's role as a facilitator in learning must be able to guide and role model students with the aim of growing digital technology competency maturity in vocational students. The more mature the level of competence in digital technology possessed by vocational teachers, the better the learning process in the formation of digital competencies for students (Lawrence \& Tar, 2018; Riyanto, Amin, Suwono, \& Lestari, 2020). This is a fundamental problem in vocational education. It was found that the level of maturity of teachers in vocational education was low. This is supported by previous research which revealed that the maturity level of digital technology for vocational education teachers in Indonesia is in a low category, both at the levels of awareness, literacy, capability, creativity, and critical of digital technology (Mutohhari et al., 2021). Problems that occur in teachers and students in mastering digital technology competencies must be addressed immediately. Vocational education must provide digital technology education and training to teachers intensively and thoroughly. Vocational teachers must also receive training on how to teach and mature digital technology to students appropriately (Kivunja, 2013; Prasasti, Solin, \& Hadi, 2019). In addition, it is very important for vocational education to harmonize digital facilities and infrastructure to support digital competency-based learning (Bui \& Do Van Dung, 2019; Devi et al., 2020). 


\section{CONCLUSION}

The maturity of vocational education teachers and students in mastering digital technology at every level shows low results. Teachers and students have the same maturity in mastering digital technology and do not differ significantly at each level. Both teachers and students have matured that falls into the low category at the level of digital technology care, digital technology literacy and digital technology capabilities. Meanwhile, teachers and students have matured that falls into the very low category at the level of creativity in digital technology and critical of digital technology. Vocational education must respond to the problem of the low level of maturity of teachers and students in mastering digital technology. Digital awareness and literacy are very important to be matured as the initial foundation for mastering digital technology well. Various trainings and learning innovations that are relevant to the relevance of digital technology mastery competencies are very important to be improved.

\section{REFERENCES}

Abidah, A., Hidaayatullaah, H. N., Simamora, R. M., Fehabutar, D., \& Mutakinati, L. (2020). The Impact of Covid-19 to Indonesian Education and Its Relation to the Philosophy of "Merdeka Belajar." Studies in Philosophy of Science and Education, 1(1), 38-49. https://doi.org/10.46627/sipose.v1i1.9

Adnan, W. I. W., Wahid, N. A., Majid, N. A., Jaafar, F. W., Ismail, N. A., \& Wahab, N. A. (2020). Do We Need You?: The Roles of Teacher Supervisor in Embracing Industrial Revolution 4.0. Journal of Physics: Conference Series, 1529(4), 1-7. https://doi.org/10.1088/1742-6596/1529/4/042046.

Aina, \& Tuti. (2020). Improving Teacher Performance In Classroom Learning Process Through Collaborative Educational Supervisions In Elementary Schools. Primary Jurnal Pendidikan Guru Sekolah Dasar, 9(2). http://dx.doi.org/10.33578/jpfkip.v9i2.7894.

Akhter, Z., Malik, G., \& Plummer, V. (2021). Nurse educator knowledge, attitude and skills towards using highfidelity simulation: A study in the vocational education sector. Nurse Education in Practice, 53. https://doi.org/10.1016/j.nepr.2021.103048.

Amiti, F. (2020). Synchronous and asynchronous E-learning. European Journal of Open Education and ELearning Studies, 5(2), 60-70. https://doi.org/10.46827/ejoe.v5i2.3313.

Apriansyah, R., Fransinatra, Z., \& Ririen, D. (2020). The Influence of Instructors Competency and Facilities on The Quality of Education and Training Center (ETC) Graduates in Facing The Industrial Revolution 4.0. Jurnal Manajemen Dan Bisnis, 9(2), 13-25. https://doi.org/10.34006/jmbi.v9i2.223.

Ariebowo, T. (2021). Autonomous learning during COVID-19 pandemic: Students objectives and preferences. Journal of Foreign Language Teaching and Learning, 6(1), 56-77. https://doi.org/10.18196/ftl.v6i1.10079.

Artacho, E. G., Martínez, T. S., Ortega Martín, J. L., Marín Marín, J. A., \& García, G. G. (2020). Teacher training in lifelong learning-the importance of digital competence in the encouragement of teaching innovation. Sustainability (Switzerland), 12(7), 1-13. https://doi.org/10.3390/su12072852.

Atmojo, A. E. P., \& Nugroho, A. (2020). EFL classes must go online! Teaching activities and challenges during COVID-19 pandemic in Indonesia. Register Journal, 13(1), 49-76. https://doi.org/10.18326/rgt.v13i1.49-76.

Barragán-Sánchez, R., Corujo-Vélez, M. C., Palacios-Rodríguez, A., \& Román-Graván, P. (2020). Teaching digital competence and eco-responsible use of technologies: Development and validation of a scale. Sustainability (Switzerland), 12(18), 1-13. https://doi.org/10.3390/su12187721.

Bayles, J., Peterson, A. D., Pitts, S. J., Bian, H., Burkholder, S., Hegde, A. V., \& Stage, V. C. (2021). FoodBased Science, Technology, Engineering, Arts, and Mathematics (STEAM) Learning Activities May Reduce Decline in Preschoolers' Skin Carotenoid Status. Journal of Nutrition Education and Behavior, 53(4). https://doi.org/10.1016/j.jneb.2020.10.017.

Beck, E., Goin, M. E., Ho, A., Parks, A., \& Rowe, S. (2021). Critical digital literacy as method for teaching tactics of response to online surveillance and privacy erosion. Computers and Composition. https://doi.org/10.1016/j.compcom.2021.102654.

Bergdahl, N., Nouri, J., \& Fors, U. (2020). Disengagement, engagement and digital skills in technologyenhanced learning. Education and Information Technologies, 25(2), 957-983. https://doi.org/10.1007/s10639-019-09998-w.

Bui, V. H., \& Do Van Dung. (2019). Development of Vietnamese Vocational Education Teachers to adapt the Industrial Revolution 4.0. Asian Journal of Interdisciplinary Research, 2(4), 1-7. https://doi.org/10.34256/ajir1941.

Chang, H.-Y., Wu, H.-F., Chang, Y.-C., Tseng, Y.-S., \& Wang, Y.-C. (2021). The effects of a virtual simulationbased, mobile technology application on nursing students' learning achievement and cognitive load: 
Randomized controlled trial. International Journal of Nursing Studies, 120. https://doi.org/10.1016/j.ijnurstu.2021.103948.

Chang, Hong, G., Paganelli, C., Phantumvanit, P., Chang, W. J., Shieh, Y. S., \& Hsu, M. L. (2020). Innovation of dental education during COVID-19 pandemic. Journal of Dental Sciences, 1(155). https://doi.org/10.1016/j.jds.2020.07.011.

Cloonan, M. R., Cloonan, D. J., Schlitzkus, L. L., \& Fingeret, A. L. (2020). Learners with Experience in Surgical Scrub Benefit from Additional Education with an Interactive E-Learning Module. Journal of the American College of Surgeons, 4(2). https://doi.org/10.1016/j.jamcollsurg.2020.08.521.

Deja, M., Rak, D., \& Bell, B. (2021). Digital transformation readiness: perspectives on academia and library outcomes in information literacy. The Journal of Academic Librarianship, 47(5). https://doi.org/10.1016/j.acalib.2021.102403.

Devi, M., Annamalai, M. A. R., \& Veeramuthu, S. P. (2020). Literature education and industrial revolution 4.0. Universal Journal of Educational Research, 8(3), $1027-1036$. https://doi.org/10.13189/ujer.2020.080337.

Dong, C., Cao, S., \& Li, H. (2020). Young children's online learning during COVID-19 pandemic: Chinese parents' beliefs and attitudes. Children and Youth Services Review, 118(June), 105440. https://doi.org/10.1016/j.childyouth.2020.105440.

Falloon, G. (2020). From digital literacy to digital competence: the teacher digital competency (TDC) framework. Educational Technology Research and Development, 68(5), 2449-2472. https://doi.org/10.1007/s11423-020-09767-4.

Garad, A., Al-Ansi, A. M., \& Qamari, I. N. (2021). The Role Of E-Learning Infrastructure And Cognitive Competence In Distance Learning Effectiveness During The Covid-19 Pandemic. Cakrawala Pendidikan, 40(1). https://doi.org/10.21831/cp.v40i1.33474.

Hanik, E. U. (2020). Self directed learning berbasis literasi digital pada masa pandemi covid-19 di Madrasah Ibtidaiyah. ELEMENTARY: Islamic Teacher Journal, 183. https://doi.org/10.21043/elementary.v8i1.7417.

Hendawi, M., \& Nosair, M. R. (2020). Students' technological awareness at the College of Education, Qatar University. Cypriot Journal of Educational Sciences, 15(4), 749-765. https://doi.org/10.18844/cjes.v15i4.5057.

Hussin, A. A. (2018). Education 4.0 Made Simple: Ideas For Teaching. International Journal of Education and Literacy Studies, 6(3). http://dx.doi.org/10.7575/aiac.ijels.v.6n.3p.92.

Ivanov, D., Dolgui, A., \& Sokolov, B. (2019). The impact of digital technology and Industry 4.0 on the ripple effect and supply chain risk analytics. International Journal of Production Research, 57(3), 829-846. https://doi.org/10.1080/00207543.2018.1488086.

Jang, M., Aavakare, M., Nikou, S., \& Kim, S. (2021). The impact of literacy on intention to use digital technology for learning: A comparative study of Korea and Finland. Telecommunications Policy, 45(7). https://doi.org/10.1016/j.telpol.2021.102154.

Jogezai, N. A., Baloch, F. A., Jaffar, M., Shah, T., Khilji, G. K., \& Bashir, S. (2021). Teachers' Attitudes Towards Social Media (SM) Use in Online Learning Amid The COVID-19 Pandemic: The Effects of SM Use by Teachers and Religious Scholars During Physical Distancing. Journal Heliyon, 7(4), 1-9. https://doi.org/10.1016/j.heliyon.2021.e06781.

Jones, M. D., Hutcheson, S., \& Camba, J. D. (2021). Past, present, and future barriers to digital transformation in manufacturing: A review. Journal of Manufacturing Systems, 15. https://doi.org/10.1016/j.jmsy.2021.03.006.

Kergroach, S. (2017). Industry 4.0: New challenges and opportunities for the labour market. Foresight and STI Governance, 11(4), 6-8. https://doi.org/10.17323/2500-2597.2017.4.6.8.

Kim, S., Heo, G., Zio, E., Shin, J., \& Song, J. (2020). Cyber attack taxonomy for digital environment in nuclear power plants. Nuclear Engineering and Technology, 52(5). https://doi.org/10.1016/j.net.2019.11.001.

Kivunja, C. (2013). Embedding Digital Pedagogy in Pre-Service Higher Education to Better Prepare Teachers for the Digital Generation. International Journal of Higher Education, 2(4), 131-142. https://doi.org/10.5430/ijhe.v2n4p131.

Lange, S., Pohl, J., \& Santarius, T. (2020). Digitalization and energy consumption. Does ICT reduce energy demand? Ecological Economics, 176. https://doi.org/10.1016/j.ecolecon.2020.106760.

Lase, D. (2019). Pendidikan di Era Revolusi Industri 4.0. Jurnal Sundermaan, 1(1). https://doi.org/10.36588/sundermann.v1i1.18.

Lawrence, J. E., \& Tar, U. A. (2018). Factors that influence teachers' adoption and integration of ICT in teaching/learning process. Educational Media International, 55(1), 79-105. https://doi.org/10.1080/09523987.2018.1439712.

Liang, Q., Torre, J. de la, \& Law, N. (2021). Do background characteristics matter in Children's mastery of 
digital literacy? A cognitive diagnosis model analysis. Computers in Human Behavior, 122. https://doi.org/10.1016/j.chb.2021.106850.

Lindvig, K., \& Mathiasen, H. (2020). Translating the Learning Factory model to a Danish Vocational Education Setting. Translating the Learning Factory Model to a Danish Vocational Education Setting, 45. https://doi.org/10.1016/j.promfg.2020.04.077.

Llopis-Albert, C., Rubio, F., \& Valero, F. (2021). Impact of digital transformation on the automotive industry. Technological Forecasting and Social Change, 162(1), 1-9. https://doi.org/10.1016/j.techfore.2020.120343.

Malik, R. S. (2018). Educational Challenges in 21st Century and Sutainable Development. Journal of Sustainable Development Education and Research, 2(1), 9-20. https://doi.org/10.17509/jsder.v2i1.12266.

Mardapi, D. (2012). Pengukuran, Penilaian, dan Evaluasi Pendidikan. Yogyakarta: Mitra Cendekia Press.

Miller, A. (2020). Development through vocational education. The lived experiences of young people at a vocational education, training restaurant in Siem Reap, Cambodia. Heliyon, 6(12). https://doi.org/10.1016/j.heliyon.2020.e05765.

Miranda, J., Navarrete, C., Noguez, J., Molina-Espinosa, J.-M., Ramírez-Montoya, M.-S., Navarro-Tuch, S. A., ... Bustamante-Bello, M.-R. (2021). The core components of education 4.0 in higher education: Three case studies in engineering education. Computers \& Electrical Engineering, 93. https://doi.org/10.1016/j.compeleceng.2021.107278.

Mulyanto, B. S., Sadono, T., Koeswanti, H. D., Dasar, S., Wonodoyo, N., Tengah, J., ... Tengah, J. (2020). Evaluation of Critical Thinking Ability with Discovery Lerning Using Blended Learning Approach in Primary School. Journal of Educational Research and Evaluation, 9(2), 78-84. https://doi.org/10.15294/jere.v9i2.46135.

Mutohhari, F., Sofyan, H., \& Nurtanto, M. (2021). Technological Competencies: A Study on the Acceptance of Digital Technology on Vocational Teachers in Indonesia. Proceedings of the 1st International Conference on Law, Social Science, Economics, and Education, ICLSSEE 2021, 1-11. https://doi.org/10.4108/eai.6-3-2021.2305971.

Neupokoeva, E., Chapaev, N., Suslova, I., Khokhlova, N., \& Sosnin, A. (2021). The development of a systems mindset in the first-year students studying online at a vocational pedagogical university while mastering the basics of working with digital technologies. Thinking Skills and Creativity, 39. https://doi.org/10.1016/j.tsc.2020.100753.

Nugroho, A., Ilmiani, D., \& Rekha, A. (2021). EFL Teachers' Challenges and Insights of Online Teaching amidst Global Pandemic. Metathesis: Journal of English Language, Literature, and Teaching, 4(3), 277. https://doi.org/10.31002/metathesis.v4i3.3195.

Nurtanto, M., Sofyan, H., Fawaid, M., \& Rabiman, R. (2019). Problem-based learning (PBL) in industry 4.0: Improving learning quality through character-based literacy learning and life career skill (LL-LCS). Universal Journal of Educational Research, 7(11), 2487-2494. https://doi.org/10.13189/ujer.2019.071128.

Ollikainen, J.-P., \& Karhunen, H. (2021). A tale of two trade-offs: Effects of opening pathways from vocational to higher education. Economics Letters, 205. https://doi.org/10.1016/j.econlet.2021.109945.

Partovi, T., \& Razavi, M. R. (2019). The effect of game-based learning on academic achievement motivation of elementary school studentsNo Title. Learning and Motivation, 68. https://doi.org/10.1016/j.lmot.2019.101592.

Pavlova, M. (2009). Technology and Vocational Education for Sustainable Development. Queensland: Springer Science Business Media B.V.

Pershina, R., Soppe, B., \& Thune, T. M. (2019). Bridging analog and digital expertise: Cross-domain collaboration and boundary-spanning tools in the creation of digital innovation. Research Policy, 48(9). https://doi.org/10.1016/j.respol.2019.103819.

Prasasti, T. I., Solin, M., \& Hadi, W. (2019). The Effectiveness of Learning Media Folklore Text of North Sumatera Based on Blended Learning by 10th Grade Students of Vocational High SchoolHarapan Mekar-1 Medan. Bir-Le Journal, 4(2). https://doi.org/10.33258/birle.v2i4.548.

Purnama, S., Ulfah, M., Machali, I., Wibowo, A., \& Narmaditya, B. S. (2021). Does digital literacy influence students' online risk? Evidence from Covid-19. Heliyon, 7(6). https://doi.org/10.1016/j.heliyon.2021.e07406.

Rea, L. M., \& Parker, R. A. (2014). Designing and Conducting Survey Research: A Comprehensive Guide, 4th Edition. San Francisco: Jossey-Bass.

Riyanto, R., Amin, M., Suwono, H., \& Lestari, U. (2020). The New Face of Digital Books in Genetic Learning: A Preliminary Development Study for Students' Critical Thinking. International Journal of Emerging Technologies in Learning (IJET), 15(10), 175. https://doi.org/10.3991/ijet.v15i10.14321. 
Rizaldi, D. R., Nurhayati, E., \& Fatimah, Z. (2020). The Correlation of Digital Literation and STEM Integration to Improve Indonesian Students' Skills in 21st Century. International Journal of Asian Education, 1(2), 73-80. https://doi.org/10.46966/ijae.v1i2.36.

Ronzhina, N., Kondyurina, I., Voronina, A., Igishev, K., \& Loginova, N. (2021). Digitalization of Modern Education: Problems and Solutions. International Journal of Emerging Technologies in Learning, 16(4), 122-135. https://doi.org/10.3991/ijet.v16i04.18203.

Rotatori, D., Lee, E. J., \& Sleeva, S. (2021). The evolution of the workforce during the fourth industrial revolution. Human Resource Development International, 24(1), 92-103. https://doi.org/10.1080/13678868.2020.1767453.

Sadaf, A., \& Johnson, B. L. (2017). Teachers' Beliefs About Integrating Digital Literacy Into Classroom Practice: An Investigation Based on the Theory of Planned Behavior. Journal of Digital Learning in Teacher Education, 33(4), 129-137. https://doi.org/10.1080/21532974.2017.1347534.

Sadeghi, A., \& Sadeghi, A. (2012). The relevance of Mastery Learning (ML) in Teaching of English (Case Study of the University of Guilan, Iran). Creative Education, 3(1). https://doi.org/http://dx.doi.org/10.4236/ce.2012.31007.

Sari, Sinaga, Hernani, \& Solfarina. (2020). Chemistry Learning via Distance Learning during the Covid-19 Pandemic. TADRIS (Journal of Education and Teacher Training), 5(1). https://doi.org/https://doi.org/10.24042/tadris.v5i1.6346.

Sert, N., \& Boynueğri, E. (2017). Digital technology use by the students and english teachers and self-directed language learning. World Journal on Educational Technology: Current Issues, 9(1), 24. https://doi.org/10.18844/wjet.v9i1.993.

Shahroom, A. A., \& Hussin, N. (2018). Industrial Revolution 4.0 and Education. International Journal of Academic Research in Business and Social Sciences, 8(9). https://doi.org/10.6007/IJARBSS/v8-i9/4593.

Silalahi, M. V. (2020). Development of E-Modules Based on Exe-Learning on Topics of Reaction Rate Against Student Learning Outcomes Mechanical Engineering. International Journal of Education and Research and Curriculum Application, 3(2), 114-120. https://doi.org/10.31764/ijeca.v3i2.2672.

Sprenger, D. A., \& Schwaninger, A. (2021). Technology acceptance of four digital learning technologies (classroom response system, classroom chat, e-lectures, and mobile virtual reality) after three months' usage. International Journal of Educational Technology in Higher Education, 18(1), 1-17. https://doi.org/10.1186/s41239-021-00243-4.

Sudana, I., Apriyani, D., \& Nurmasitah, S. (2019). Revitalization of vocational high school roadmap to encounter the 4.0 industrial revolution. Journal of Social Sciences Research, 5(2), 338-342. https://doi.org/10.32861/jssr.52.338.342.

Sudira, P. (2020). Paradigma Baru Pembelajaran Vokasional Era Revolusi Industri 4.0. Yogyakarta: UNY PRESS.

Sugiyono. (2017). Metode Penelitian Kuantitatif, Kualitatif, dan R\&D. Bandung: Alfabeta.

Tham, J. C. K., Burnham, K. D., Hocutt, D. L., \& Ranade, N. (2021). Metaphors, Mental Models, and Multiplicity: Understanding Student Perception of Digital Literacy. Computers and Composition, 59. https://doi.org/10.1016/j.compcom.2021.102628.

Trilling, B., \& Fadel, C. (2009). 21st Century Skills: Learning for Life in Our Times. San Francisco: JosseyBass.

van Wyk, R. J. (2020). Towards technological awareness and wisdom. South African Journal of Industrial Engineering, 31(4), 1-8. https://doi.org/10.7166/31-4-2274.

Willya, Poluakan, Dikayuana, Wibowo, \& Raharjo. (2019). Generasi Milenial Pada Era Revolusi Industri 4.0. Focus : Jurnal Pekerjaan Sosial, 2(2). https://doi.org/10.24198/focus.v2i2.26241.

Xu, M., David, J. M., \& Kim, S. H. (2018). The fourth industrial revolution: Opportunities and challenges. International Journal of Financial Research, 9(2), 90-95. https://doi.org/10.5430/ijfr.v9n2p90.

Yazar Soyad, B. B. (2015). Creative and Critical Thinking Skills in Problem-based Learning Environments. Journal of Gifted Education and Creativity, 2(2), 71-71. https://doi.org/10.18200/jgedc.2015214253.

Yustina, Syafii, W., \& Vebrianto, R. (2020). The effects of blended learning and project-based learning on preservice biology teachers' creative thinking skills through online learning in the COVID-19 pandemic. Jurnal Pendidikan IPA Indonesia, 9(3), 408-420. https://doi.org/10.15294/jpii.v9i3.24706.

Zhao, Y., Llorente, A. M. P., \& Gómez, M. C. S. (2021). Digital competence in higher education research: A systematic literature reviewNo Title. Computers \& Education, 168. https://doi.org/10.1016/j.compedu.2021.104212.

Zimmer, W. K., McTigue, E. M., \& Matsuda, N. (2021). Development and validation of the teachers' digital learning identity survey. International Journal of Educational Research, 105. https://doi.org/10.1016/j.ijer.2020.101717. 